\title{
非高温下でのオクラ種子出芽を促進する培養土プライミング
}

\author{
高畑 健 $*$ •三浦周行 ${ }^{\mathrm{a}}$ \\ 東京農業大学農学部 243-0034 神奈川県厚木市船子
}

\section{Priming with Seeding Mixture to Improve Emergence from Okra Seeds at Non-High-Temperature}

\author{
Ken Takahata* and Hiroyuki Miura ${ }^{\mathrm{a}}$ \\ Department of Agriculture, Tokyo University of Agriculture, Atsugi, Kanagawa 243-0034
}

\begin{abstract}
A study was conducted to develop a simple priming method to improve seedling emergence of okra seeds in non-hightemperature seasons using a seeding mixture as a moisture-conditioning agent. 'Tokyo Gokaku' seeds were primed in bottles at 15 to $30^{\circ} \mathrm{C}$ for 1 to 4 days with seeding mixtures having moisture contents ranging from 35 to $55 \%$. After treatment, seeds were sown in containers at $20^{\circ} \mathrm{C}$. Seedling emergence was markedly promoted under the conditions of $30^{\circ} \mathrm{C} / 1 \mathrm{~d} / 45 \%$ moisture: the percentage emergence at 8 days after sowing was $94 \%$, whereas emergence was $53 \%$ in the non-treated control. The seeds sown directly in the field in May after priming $\left(30^{\circ} \mathrm{C} / 1 \mathrm{~d} / 45 \%\right.$ moisture) emerged earlier and grew into seedlings with a more uniform top fresh weight compared with the non-treated seeds. The seeds kept at room temperature for several days after priming $\left(30^{\circ} \mathrm{C} / 1 \mathrm{~d} / 45 \%\right.$ moisture $)$ and sown in the field in May showed no differences in emergence compared with seeds sown just after priming. Priming in this study improved emergence, and the effects were maintained even in seeds that were temporarily stored after treatment to simulate postponed sowing.
\end{abstract}

Key Words : Abelmoschus esculentus, percentage emergence, seed treatment

キーワード : Abelmoschus esculentus, 種子処理, 出芽率

\section{緒言}

オクラ (Abelmoschus esculentus (L.) Moench) は,アオイ 科に属し，原産が東北アフリカあるいは北インドとされ (Hamon・Sloten, 1995), 熱帯地域で広く栽培されている高 温性の野菜である. 日本に扣いては鹿児島県，高知県扣よ び沖縄県などで周年生産されているが（園芸統計，2011）， 種子出芽の適温が $35^{\circ} \mathrm{C}$ と高温なので（Takahata ら，2011）, $20^{\circ} \mathrm{C}$ 前後のような非高温期播種では, 出芽の欠損, 遅延, 不揃いが問題になる。 その対策として, 催芽処理および育 苗床を高温に維持することなどが考えられるが，それぞれ 播種時の作業性および加温装置の整備が課題である.

種子の発芽・出芽を促進する方法として, 播種前の種子 に幼根が突出しない程度のわずかな水分を与え, 種子内部 の生理過程を発芽直前の段階まで進めておく種子処理であ るプライミングがあり，オクラ種子に対しても有効なこと が報告されている（Dkhilら，2014; Nirmala・Umarani, 2008;

2016 年 3 月 8 日 受付. 2016 年 5 月 12 日 受理.

本論文の一部は園芸学会平成 22 年度秋季大会で発表した。

* Corresponding author. E-mail: k5takaha@nodai.ac.jp

a 退職
Sharma ら, 2014; Singh ら，2004). しかし，プライミング は実際栽培では普及していない，農家にとってはそれらの プライミングに用いられるポリエチレングリコール溶液, 塩類溶液，岩石資材および多孔質資材などが一般的でな い，あるいは処理中エアレーションもしくは処理後水洗の 必要があり処理が簡易でないためと考えられる，著者らは 農業で一般的な培養土を用いて，容易にプライミングがで きないか考えた。そこで，非高温下に拈けるオクラ種子の 出芽を促進させるために, 市販されている培養土を処理資 材として，農家が容易に実施可能な培養土に種子を混ぜ込 むだけの培養土プライミングの開発を試みた。

\section{材料および方法}

ガラス瓶 $(200 \mathrm{~mL})$ に, 湿重当たりの水分含量を 35 , 45 および 55\%に調節した野菜セル育苗用培養土（ $\mathrm{N}: \mathrm{P}_{2} \mathrm{O}_{5}$ : $\mathrm{K}_{2} \mathrm{O}=150: 1000: 150 \mathrm{mg} \cdot \mathrm{L}^{-1}$, ジェイカムアグリ(株)）約 $90 \mathrm{~g}$ 特よび “東京五角”（(株）武蔵野種苗園）種子 60 粒を 入れ，混合後蓋をした，それらの瓶を， $15^{\circ} \mathrm{C} ・ 4$ 日間（実 験 1 ）， $22.5^{\circ} \mathrm{C} ・ 1$ 日間（実験 $2 ）$ 打よび $30^{\circ} \mathrm{C} ・ 1$ 日間（実 験 3), 処理室 (LH-200, (株) 日本医化機器製作所; 暗黒) に置き，培養土プライミングを施した。なお，各処理区に 打けるプライミング開始時の培養土水ポテンシャルを，水 
ポテンシャル測定装置（WP4C, Decagon Devices）で調査 した.

処理終了後，種子を網目サイズが $3 \mathrm{~mm}$ の篩で分け，30 分間風乾した，その後，上記の培養土を詰めたプラスチッ ク容器（縦 $19 \mathrm{~cm} \times$ 横 $13 \mathrm{~cm} \times$ 高さ $6 \mathrm{~cm}$, 底の 4 か所に直径 $4 \mathrm{~mm}$ の排水穴）に，処理種子抏よび無処理種子ともに 50 粒を $1 \mathrm{~cm}$ の深さに播種し（株間 $1.5 \mathrm{~cm}$, 条間 $2 \mathrm{~cm}$ の 5 条 播き), 十分に灌水した。. 各プラスチック容器を $20^{\circ} \mathrm{C}$ に制 御した出芽室（LH-200; 明期 1 日 12 時間, 光合成光量子 束密度平均 $\left.111 \mu \mathrm{mol} \cdot \mathrm{m}^{-2} \cdot \mathrm{s}^{-1}\right)$ に移した. 翌日から播種 した時刻とほぼ同じ時刻に出芽率を10日間毎日調査し, 平均出芽日数も求めた. 調査期間中, 播種後 4 日と 8 日に 灌水した. 以上の各実験に打いて, 各処理区のプライミン グに瓶 2 個および播種に容器 2 個を用い, また無処理区の 播種にも容器を 2 個用いて, 実験を 3 回反復した. 出芽率 扣よび平均出芽日数について, 得られた各 6 データの平均 值の差をテューキー検定（5\%水準）した.

次に, 実験 4 で培養土プライミング種子の圃場に扣ける 出芽を検討した. 実験 1 ～ 3 の結果をもとに, 出芽が良好 であった温度 $30^{\circ} \mathrm{C} /$ 処理 1 日 / 培養土水分含量 $45 \%$ (以 下， $30^{\circ} \mathrm{C} / 1$ 日 $/ 45 \%$ と略称，以下も同様）での処理種子 （3 瓶）を固場に 2011 年 5 月 11 日に播種した。 1 条ずつ無 処理区と処理区が交互になるよらに条間 $10 \mathrm{~cm}$ で計 6 条 （幅 $1 \mathrm{~cm}$, 深さ $1 \mathrm{~cm}$ ) を設け, 各条に50粒の種子を播種 した.なお，処理区については各処理瓶の種子を各条に播 種した。 また，6条の両側には無処理種子を播種した調査 対象外の条を設けた. 播種後, 覆土・灌水し, 翌日から毎 日，播種した時刻とほぼ同じ時刻に灌水と同時に出芽率を 10 日間 (最低気温: $10 \sim 16^{\circ} \mathrm{C}$, 最高気温: $16 \sim 32^{\circ} \mathrm{C}$, 平 均気温: $\left.20.1^{\circ} \mathrm{C}\right)$ 調査し, 調査最終日には出芽個体の地上 部新鮮重も測定した. 各区とも条ごとで 1 反復とし, 合計 3 反復とした. 得られた出芽率, 平均出芽日数および地上 部新鮮重の平均值の差を $\mathrm{t}$ 検定（5\%水準）した.

さらに，処理終了当日に播種できない場合に備えて，実 験 5 で処理種子の一時的保管が出芽に及ぼす影響を検討し た. $30^{\circ} \mathrm{C} / 1$ 日 $/ 45 \%$ 処理後, 種子を篩で分けて 30 分間 風乾し, 新しい瓶に処理種子を移して蓋をした。種子を入 れた瓶を室温下暗所で 3 日間（最高温度 : $21.7 \sim 22.9^{\circ} \mathrm{C}$, 最低温度: $19.1 \sim 20.2^{\circ} \mathrm{C}$, 平均温度 : $\left.21.1^{\circ} \mathrm{C}\right)$ および 7 日 間（最高温度: $20.6 \sim 22.9^{\circ} \mathrm{C}$, 最低温度 : $18.5 \sim 20.2^{\circ} \mathrm{C}$, 平均温度 : $20.7^{\circ} \mathrm{C}$ ) 終了日を同一として保管した。保管終 了後, 0 日間保管区抒よび無処理区も加え, 実験 4 と同様 に固場に 2013 年 5 月 8 日に播種した。出芽率を播種後 8 日間 (最低気温: $10 \sim 16^{\circ} \mathrm{C}$, 最高気温: $16 \sim 31^{\circ} \mathrm{C}$, 平均 気温: $19.3^{\circ} \mathrm{C}$ ) 調査し, 調査最終日には地上部新鮮重も測 定した. 実験は上記 4 区を 3 反復で行った. 得られた出芽 率, 平均出芽日数扮よび地上部新鮮重の平均值の差を テューキー検定 (5\%水準) した.

\section{結果および考察}

実験 $1 \sim 3$ に打いて, 計 9 条件で培養土プライミングし た種子を $20^{\circ} \mathrm{C}$ 出芽室内で播種し, 好適条件を検討した. プライミング開始時に拈ける培養土の水ポテンシャル

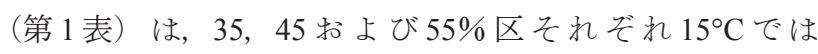
$-0.29,-0.23$ および-0.17 MPa, $22.5^{\circ} \mathrm{C}$ では $-0.48,-0.33$ および-0.26 MPa, $30^{\circ} \mathrm{C}$ では $-0.57,-0.51$ および-0.38 MPa であった。

実験 1 〜 3 打ける出芽率および平均出芽日数を第 2 表 に示した.

実験 1 の無処理区の出芽は播種後 6 日に開始し (3\%), 8 日に $58 \% ， 9$ 日に $82 \%$ となった. $15^{\circ} \mathrm{C} / 4$ 日 $/ 35 \sim 55 \%$ 区の出芽は播種後 5 日に開始し $(5 \sim 11 \%), 6$ 日に $38 \sim$ 60\%, 8 日に $86 〜 89 \%$ となり，この間無処理区より優れた. 平均出芽日数は無処理区の 8.14 日に対して, 3 処理区が $6.29 \sim 6.64$ 日と短く, 無処理区との差は $15^{\circ} \mathrm{C} / 4$ 日 $/ 45 \%$ 区で大きかった.

実験 2 の無処理区の出芽は播種後 6 日に開始し $(3 \%)$, 8 日に $63 \%$ ，9日に $81 \%$ となった. $22.5^{\circ} \mathrm{C} / 1$ 日 $/ 35$ ○ $55 \%$ 区の出芽は播種後 5 日に開始し $(3 \sim 7 \%)$ ，6 日に $27 \sim 41 \% ， 8$ 日に $84 〜 89 \%$ となり，この間無処理区より 勝った. 播種後 $9 〜 10$ 日に扣いては $22.5^{\circ} \mathrm{C} / 1$ 日 $/ 45 \%$ 区 の出芽が無処理区より勝った. 平均出芽日数は 3 処理区が 無処理区より短かった.

さらに, 実験 3 の無処理区の出芽も播種後 6 日に開始し (1\%)，8日に $53 \% ， 9$ 日に $75 \%$ となった. $30^{\circ} \mathrm{C} / 1$ 日 $35 \sim 55 \%$ 区の出芽は播種後 5 日に開始し $(7 \sim 15 \%), 6$ 日に52〜73\%，8日に90〜94\%となり，以降 9 日まで無 処理区よりも勝り，その間の 6 日の $30^{\circ} \mathrm{C} / 1$ 日 $/ 45 \%$ 区の 出芽率は無処理区との差が大きかった．播種後 10 日の出 芽は $30^{\circ} \mathrm{C} / 1$ 日 $/ 45 \%$ 区が無処理区より高かった. 平均出 芽日数は 3 処理区で短く, 無処理区との差は $30^{\circ} \mathrm{C} / 1$ 日 45\%区で大きかった.

以上のよらに実験 $1 \sim 3$ のいずれの処理によっても出芽 が促進される傾向にあった。特に播種後 6 日の出芽率の 促進が顕著で，無処理区の $1 \sim 3 \%$ に対して，処理区では $27 〜 73 \%$ であった. すべての処理区の出芽率について, 各処理を行った実験に打ける無処理区の值に対する比数で 比較すると，播種後 6〜9 日に拈いて $30^{\circ} \mathrm{C} / 1$ 日 $/ 45 \%$ 区

第1表 プライミング開始時に括ける培養土の水ポテンシャ ル $(\mathrm{MPa})$

\begin{tabular}{cccc}
\hline \hline \multirow{2}{*}{ 処理温度 } & \multicolumn{3}{c}{ 培養土水分 } \\
\cline { 2 - 4 } & $35 \%$ & $45 \%$ & $55 \%$ \\
\hline $15^{\circ} \mathrm{C}$ & -0.29 & -0.23 & -0.17 \\
$22.5^{\circ} \mathrm{C}$ & -0.48 & -0.33 & -0.26 \\
$30^{\circ} \mathrm{C}$ & -0.57 & -0.51 & -0.38 \\
\hline
\end{tabular}




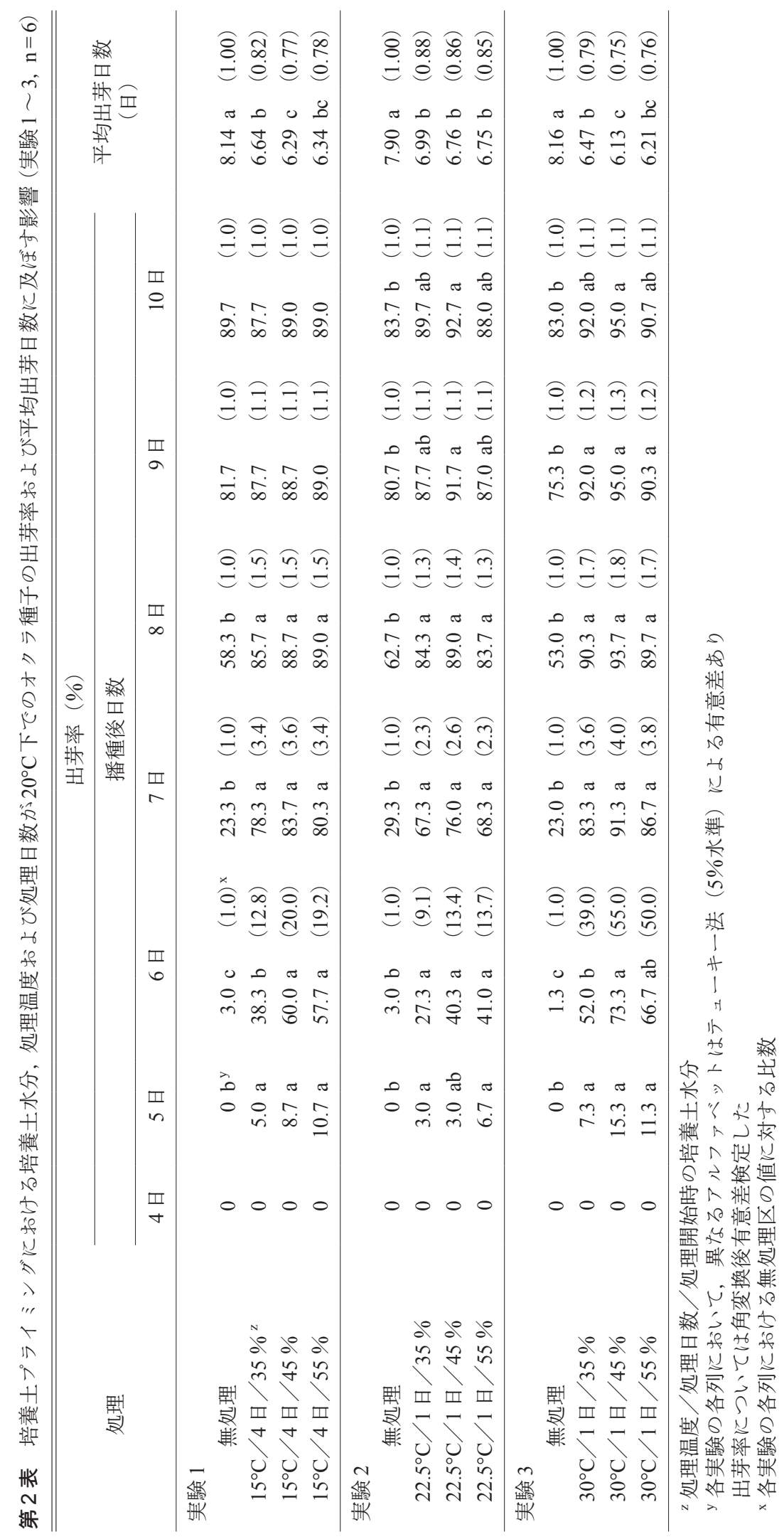




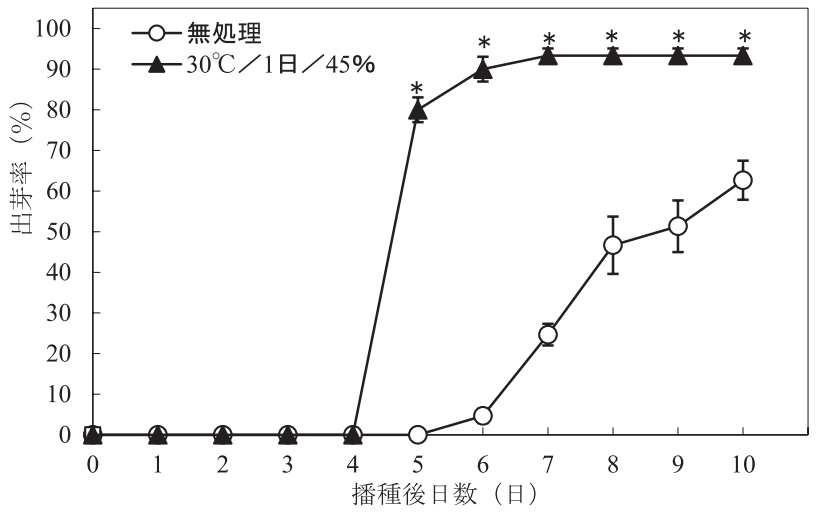

第 1 図 培養土プライミング種子の 5 月固場播種後に打ける 出芽経過（実験 4, n=3）

$30^{\circ} \mathrm{C} / 1$ 日 $/ 45 \%$ : 処理温度 /処理日数 /処理開始時 の培養土水分

* : 両区間に $\mathrm{t}$ 検定（5\%水準）による有意差あり 出芽率については角変換後有意差検定した 縦線：SE

が高い值を示した。 また平均出芽日数の比数でも $30^{\circ} \mathrm{C} / 1$ 日 $/ 45 \%$ 区が低い值を示した。従って，30 ${ }^{\circ} \mathrm{C} / 1$ 日 $/ 45 \%$ 区が好適と判断された。

実験 4 に扮いて, 実験 1 ～ 3 の結果から好適とされた $30{ }^{\circ} \mathrm{C} / 1$ 日 $/ 45 \%$ 処理種子を 5 月に戒場に播種した結果を 第 1 図抽び第 3 表に示した. 無処理区の出芽は播種後 6 日に開始し $(5 \%) ， 7$ 日に25\%，10日に63\%となった。 一方， $30^{\circ} \mathrm{C} / 1$ 日 $/ 45 \%$ 区の出芽は播種後 5 日に開始し, $80 \%$ であった. 播種後 10 日までの平均出芽日数は処理区 で短かった. 播種後 10 日の地上部重は処理区が大きく, その変動係数は処理区が小さく, それらの無処理区との差 は第 2 図に示した画像上からも明確である.

これまでに, オクラ種子の出芽・発芽促進にはポリエチ
第 3 表 培養土プライミング種子の 5 月固場播種後に打ける 出芽打よび地上部の生育 (実験 $4, \mathrm{n}=3$ )

\begin{tabular}{|c|c|c|c|}
\hline \multirow[t]{2}{*}{ 処理 } & \multirow{2}{*}{$\begin{array}{c}\text { 平均 } \\
\text { 出芽日数 } \\
\text { (日) }\end{array}$} & \multicolumn{2}{|c|}{$\begin{array}{l}\text { 播種後 } 10 \text { 日における } \\
\text { 実生の地上部新鮮重 }\end{array}$} \\
\hline & & $(\mathrm{mg})$ & 変動係数 \\
\hline 無処理 & 7.98 & 163 & 0.52 \\
\hline $30^{\circ} \mathrm{C} / 1$ 日 $/ 45 \%{ }^{z}$ & $5.18 *$ & $216 *$ & 0.36 \\
\hline
\end{tabular}

* : 両区間に $\mathrm{t}$ 検定（5\%水準）による有意差あり

$\mathrm{z}$ 処理温度/処理日数/処理開始時の培養土水分

レングリコール溶液，塩類溶液，岩石資材および多孔質資 材を用いたプライミングが有効なことが報告されている

(Dkhil ら, 2014; Nirmala・Umarani, 2008; Sharma ら, 2014; Singh ら，2004)。 オクラ以外の種子でもプライミングの有 効性がHeydecker (1974), Khan ら (1990), Suzuki ら (1989) およびTaylorら（1988）によって報告されている。しかし ながら，これらのプライミングは実用化されていない，そ れは，処理に使ら資材が農業では一般的でないこと，処理 中エアレーションあるいは処理後水洗の必要があり, 処理 が簡易でないことが要因の一つと考えられる。 また専門業 者による処理は，処理後の流通対策を要し，コストがかか り，普及は難しい。

著者らは農業で一般的な培養土に注目し，それをプライ ミング資材として利用できるかどらかを検討してきた。 こ れまでに, 水分含量を調節した培養土を詰めたセルトレイ にッルムラサキ（Miura ら， 1997），パセリー（Miura ら， 2001）およびレタス（Takahata ら，2008）の種子を播種後, それらのトレイごと処理するプライミングが出芽促進に有 効なことを報告した。本実験ではセル育苗されないオクラ 種子に適用できる培養土を用いたプライミングを開発しよ

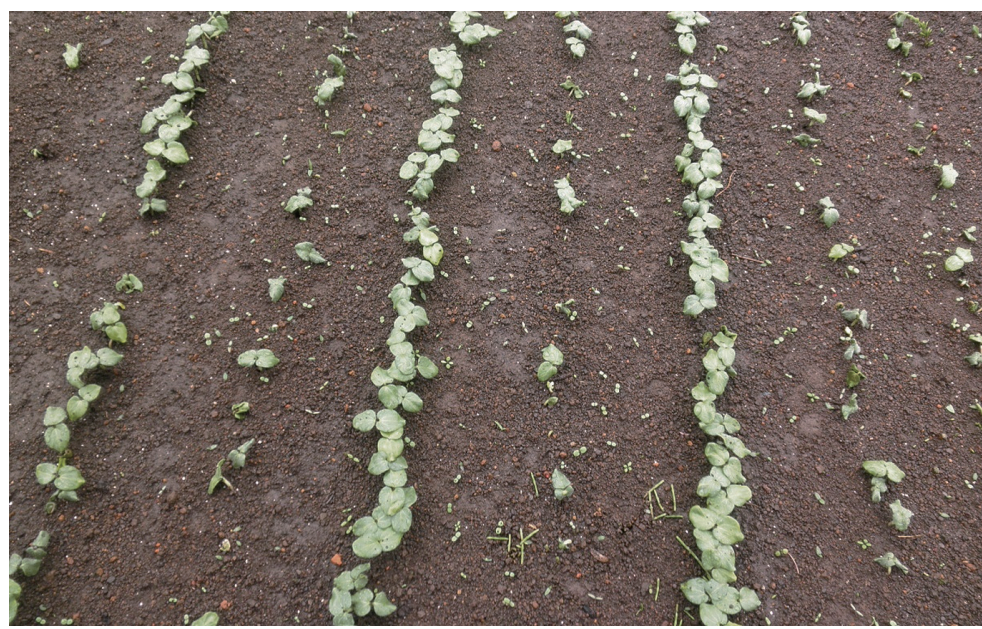

$30^{\circ} \mathrm{C} / 1$ 日 $/ 45 \%$

無処理

$30^{\circ} \mathrm{C} / 1$ 日 $/ 45^{\circ} \%$

無処理

$30^{\circ} \mathrm{C} / 1$ 日 $/ 45 \%$

無処理

第 2 図培養土プライミング種子の圃場播種後 10 日の出芽状況（実験 4) $30^{\circ} \mathrm{C} / 1$ 日 $/ 45 \%$ : 処理温度 /処理日数 /処理開始時の培養土水分 


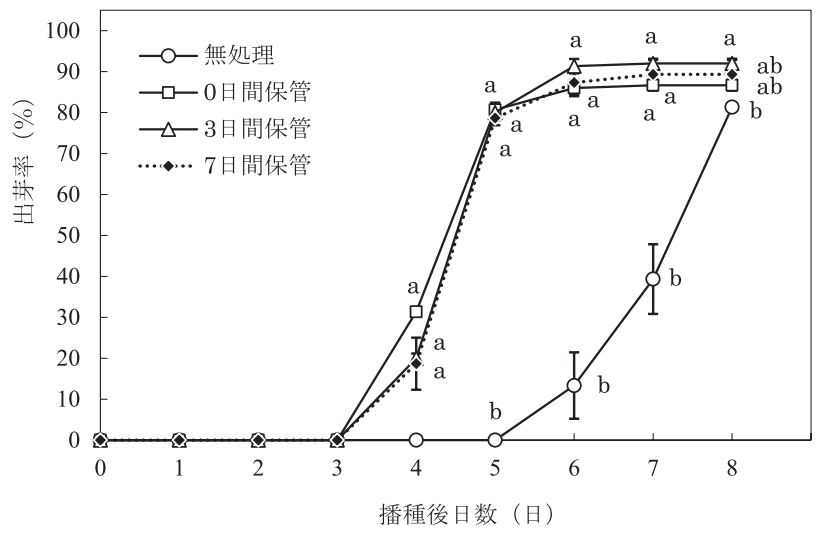

第 3 図 保管した培養土プライミング種子 $\mathrm{z}$ の 5 月圃場播種後 に打敌出芽経過（実験 $5, n=3$ ）

播種後日数内の異なるアルファベットはテューキー法 （5\%水準）による有意差あり

出芽率については角変換後有意差検定した

縦線 : SE

${ }^{\mathrm{z}} 30^{\circ} \mathrm{C} / 1$ 日 $/ 45 \%$ (処理温度 / 処理日数 / 処理開始時 の培養土水分）種子

らとした. 実験 $1 \sim 4$ の結果は, 培養土によるプライミン グはオクラ種子の出芽促進に有効なことを示した．実験 1 $\sim 3$ の結果から, 好適処理は $30^{\circ} \mathrm{C} / 1$ 日 $/ 45 \%$ 区であった が，今回使用した分を含を 5 袋の培養土の開封時の水分含 量は43\%であったので, 実際にはそのままの培養土中で $22.5 \sim 30^{\circ} \mathrm{C}$ で1日のプライミングでも高い出芽促進効果 があると考光られる。

Dkhilら（2014）の実験によると，オクラのプライミン グ種子を $20^{\circ} \mathrm{C}$ 下に置床したところ, 10 日後の発芽率は, 無処理区の 88.0\%に対して, エアレーションし KCl 4\%ま たは $\mathrm{CaCl}_{2} 10 \mathrm{mM}$ 溶液によるプライミング（処理後水洗）

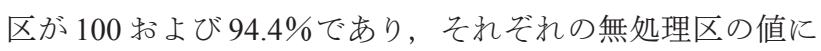
対する比数は 1.14 拉よび 1.07 であった. 実験 3 飞打いて, $30^{\circ} \mathrm{C} / 1$ 日 $/ 45 \%$ 処理種子を $20^{\circ} \mathrm{C}$ 下に播種した 10 日後の 出芽率（第2 表）は，無処理区の $83 \%$ に対して，95\%, 同区の無処理区に対する比数は 1.14 であった。従って, 両実験のプライミング効果は同等と考兄られる. 他の既報 の結果とは, 出芽・発芽条件が異なるので, 比較が難しい.

実用場面では，予定していた日に播種ができないことが 予想される. そこで処理種子の一時保管が可能かどらか検 討した実験 5 の結果を第 3 図打よび第 4 表に示した. 5 月 戋場播種の結果, 無処理区の出芽は, 播種後 6 日に開始し (13\%)，7 日には $39 \% ， 8$ 日には $81 \%$ となった． $30^{\circ} \mathrm{C} / 1$ 日 $/ 45 \%$ 処理後 $0 \sim 7$ 日間保管した区に打いては，いずれ の区も出芽が播種後 4 日に開始し $(19 \sim 31 \%) ， 5$ 日には $79 \sim 81 \%$ となり, 無処理区に比べて 8 日後までの平均出 芽日数が短く, 播種後 8 日の地上部重が大で, その変動係 数が小さかった. 従って, 処理効果は保管 7 日後も維持さ れた，このことは，本実験の培養土を用いたプライミング の実用性をさらに高めることにつながると考兄られる。 こ
第 4 表 保管した培養土プライミング種子 ${ }^{\mathrm{z}}$ の 5 月戋場播種後 に拈ける出芽扎よび地上部の生育（実験 $5, \mathrm{n}=3$ ）

\begin{tabular}{|c|c|c|c|}
\hline \multirow{2}{*}{ 処理 } & \multirow{2}{*}{$\begin{array}{l}\text { 平均 } \\
\text { 出芽日数 } \\
\text { (日) }\end{array}$} & \multicolumn{2}{|c|}{$\begin{array}{l}\text { 播種後 } 8 \text { 日に打る } \\
\text { 実生の地上部新鮮重 }\end{array}$} \\
\hline & & $(\mathrm{mg})$ & 変動係数 \\
\hline 無処理 & $7.31 \mathrm{a}^{\mathrm{y}}$ & $180 \mathrm{~b}$ & 0.28 \\
\hline 0 日間保管 & $4.74 \mathrm{~b}$ & $322 \mathrm{a}$ & 0.15 \\
\hline 3 日間保管 & $4.92 \mathrm{~b}$ & $325 \mathrm{a}$ & 0.12 \\
\hline 7 日間保管 & $4.93 \mathrm{~b}$ & $327 \mathrm{a}$ & 0.13 \\
\hline
\end{tabular}

${ }^{\mathrm{z}} 30^{\circ} \mathrm{C} / 1$ 日 $/ 45 \%$ (処理温度/処理日数/処理開始時の培 養土水分）種子

y 異なるアルファベットはテューキー法（5\%水準）による 有意差あり

れまでに，プライミングしたオクラ種子の保管性について 検討した報告はない。

本研究の結果, 圃場およびポット播種されるオクラ種子 に対する培養土プライミングは, 出芽最適温度である $35^{\circ} \mathrm{C}$ （Takahata ら，2011）よりも著しく低い $20^{\circ} \mathrm{C}$ 前後のよ らな非高温下であっても，播種後早期に高い出芽率をもた らし，その後の均一な生育を促した。 そのため, 実際栽培 に拈けるポット播種では，加温装置などにより育苗床を高 温に維持する必要がない。 また，播種後早期の出芽率が高 いことは，育苗日数を短縮させ，苗の生育揃いが斉一であ るため育苗管理が煩雑にならない，さらに，処理効果が種 子を数日間保管したとしても維持され，オクラ種子にとっ て不利な非高温期の圃場でも斉一な出芽をもたらすことが 示された，このことは，処理終了後直ちに播種をする必要 がないことを意味する。

プライミングは, Heydecker（1974）によって発表され て以降，各種の方法が報告されているが，それらは特殊な 資材・技術を要するため農家自身が容易に実施できる方法 ではなかった。 しかし, 本研究の培養土プライミングは, 種子を市販の育苗用培養土に混ぜ込むだけであり，処理後 の水洗も必要としないため, 農家自身での実施が可能であ る. そのため, 本研究によって開発された培養土プライ ミングは, 生産者に対して普及性の高い種子処理方法とし て展開できるものと考光られる。

\section{摘 要}

オクラ種子の非高温下に扔ける出芽を生産者が容易に促 進できるように，培養土を水分調節資材に用いたプライ ミングを開発しょうとした。 ‘東京五角’ 種子と $35 \sim 55 \%$ 水分含量の培養土を瓶に入れて $15 \sim 30^{\circ} \mathrm{C}$ 下で $1 \sim 4$ 日間 プライミングした後，コンテナに播種して $20^{\circ} \mathrm{C}$ 下に置い た. $30^{\circ} \mathrm{C} / 1$ 日 $/ 45 \%$ 区の出芽促進が著しく, 播種後 8 日 の出芽率が, 無処理区の $53 \%$ に対して，94\%と優孔た. $30^{\circ} \mathrm{C} / 1$ 日 $/ 45 \%$ 区の種子を 5 月に戋場播種したところ, 無処理区より出芽が早く開始し, 地上部新鮮重が均一で 
あった. $30^{\circ} \mathrm{C} / 1$ 日 $/ 45 \%$ 区の種子を数日間室温下で保管

後 5 月に圃場播種した結果, 処理終了後直ちに播種した区 と出芽特性に差がなかった. 本実験のプライミングは出芽 を促進させ，その効果は播種期の延期を想定した処理種子 保管後も維持された.

謝 辞 本研究に执いて全般的にご協力頂いた川本芳樹 扣よび庄子修平の諸氏に, また, 培養土水ポテンシャルの 測定に便宜を図って頂いたアイネクス株式会社の石川隆之 氏に感謝します。

\section{引用文献}

Dkhil, B. B., A. Issa and M. Denden. 2014. Germination and seedling emergence of primed okra (Abelmoschus esculentus L.) seeds under salt stress and low temperature. Am. J. Plant Physiol. 9: 38-45.

園芸統計. 2011. 平成 22 年度版. p. 56 . 農林水産省大臣 官房統計部. 農林統計協会. 東京.

Hamon, S. and D. H. van Sloten. 1995. Okra. p. 350-357. In: J. Smart and N. W. Simmonds (eds.). Evolution of crop plants, 2nd ed. Longman, London.

Heydecker, W. 1974. Germination of an idea: The priming of seeds. Res. Sch. Agric. Univ. Nott. 1973-1974: 50-67.

Khan, A. A., H. Miura, J. Prusinki and S. Ilyas. 1990. Matriconditioning of seeds to improve emergence. p. 19-40. In: Proc. Nat. Symp. Stand Estab. Hort. Crop. Minneapolis.

Miura, H., Y. Yamato, M. Hamano and H. Yamazaki. 2001. Improvement of emergence of parsley seeds by post-sown priming. J. Japan. Soc. Hort. Sci. 70: 665-668.

Miura, H., H. Yamazaki and T. Nishijima. 1997. Post-sown priming with a potting mixture to improve emergence of malabar spinach, Basella alba L. J. Japan. Soc. Hort. Sci. 66: 513-517.

Nirmala, K. and R. Umarani. 2008. Evaluation of seed priming methods to improve seed vigour of okra (Abelmoschus esculentus) and beetroot (Beta vulgaris). Seed Sci. Technol. 36: 56-65.

Sharma, A. D., S. V. S. Rathore, K. Srinivasan and R. K. Tyagi. 2014. Comparison of various seed priming methods for seed germination, seedling vigour and fruit yield in okra (Abelmoschus esculentus L. Moench). Scientia Hortic. 165: $75-81$.

Singh, J., J. S. Kanwar and G. Bassi. 2004. Seed vigour as influenced by different seed priming treatments in okra (Abelmoschus esculentus L. Moench). Seed Res. 32: 122125.

Suzuki, H., S. Obayashi and H. Luo. 1989. Effects of salt solutions on the priming of several vegetable seeds. J. Japan. Soc. Hort. Sci. 58: 131-138.

Takahata, K., Y. Mine, A. Karimata and H. Miura. 2008. An effective post-sown priming method to improve emergence from lettuce seeds at high temperature. HortTechnology 18: 433-435.

Takahata, K., Y. Mine and H. Miura. 2011. The optimum emergence temperature for okra seed. Trop. Agr. Develop. 55: 93-96.

Taylor, A. G., D. E. Klein and T. H. Whitlow. 1988. SMP: Solid matrix priming of seeds. Scientia Hortic. 37: 1-11. 